\title{
Water quality in individual groundwater supply systems in Southern Brazil
}

\author{
Silvana Isabel Schneider'iD, Jaqueline Ineu Golombieski'(i), \\ Debora Seben"(i), Kananda Cabral Menegazzo' (D) Arci Dirceu Wastowski'iD, \\ Willian Fernando de Borba' ${ }^{(1)}$, Samara Terezinha Decezaro'(iD, \\ Raphael Corrêa Medeiros' ${ }^{10}$
}

'Universidade Federal de Santa Maria, Santa Maria, RS, Brasil

"Universidade Estadual do Rio Grando do Sul, Porto alegre, RS, Brasil

\begin{abstract}
This study aimed to evaluate the potability of drinking water in ten municipalities of Rio Grande do Sul State, Brazil, distributed in rural and urban areas, with three different sources: springs, shallow wells, and deep wells. The water quality parameters analyzed from 2017 to 2019 were: $\mathrm{pH}$, temperature, apparent and true color, turbidity, electrical conductivity, total alkalinity, total hardness, nitrite, total phosphorus, total iron, fluoride, biochemical oxygen demand, total coliforms, and Escherichia coli. A macroscopic analysis was also conducted in the surrounding of sampling points. According to the Brazilian and the WHO (World Health Organization) guidelines, some of the analyzed variables, in some sampling points, were in disagreement with the current both guidelines, which are $\mathrm{pH}$, apparent color, turbidity, total iron, total coliforms, and Escherichia coli. The surveillance showed that the deeper the water is abstracted the less are natural and anthropogenic interferences in physical, chemical, and microbiological characteristics of the water; and the protection of the location where the water is abstracted improves its quality. Nonetheless, for the sampled waters it is necessary a disinfection process for posterior human consumption.
\end{abstract}

Keywords: Human consumption; Potability; Public Health; Water Resources 


\section{RESUMO}

Este estudo teve como objetivo avaliar a potabilidade da água em dez municípios do Estado do Rio Grande do Sul, Brasil, distribuídos nas áreas rural e urbana, com três diferentes origens: nascentes, poços rasos e poços profundos. Os parâmetros de qualidade da água analisados de 2017 a 2019 foram: $\mathrm{pH}$, temperatura, cor aparente e verdadeira, turbidez, condutividade elétrica, alcalinidade total, dureza total, nitrito, fósforo total, ferro total, fluoreto, demanda bioquímica de oxigênio, coliformes totais e Escherichia coli. A análise macroscópica também foi realizada no entorno dos pontos de amostragem. De acordo com as diretrizes brasileiras e da OMS (Organização Mundial da Saúde), algumas das variáveis analisadas, em alguns pontos de amostragem, estavam em desacordo com as duas diretrizes atuais, que são $\mathrm{pH}$, cor aparente, turbidez, ferro total, coliformes totais e Escherichia coli. O monitoramento mostrou que quanto mais profunda a captação da água, menos interferências naturais e antrópicas nas características físicas, químicas e microbiológicas da água; e a proteção do local onde a água é captada melhora sua qualidade. Porém, para as águas amostradas é necessário um processo de desinfecção para posterior consumo humano.

Palavras-chave: Consumo humano; Potabilidade; Saúde Pública; Recursos Hídricos

\section{INTRODUCTION}

Brazil is one of the countries that present the largest water availability on Earth, according to the Brazilian Water Agency, however, with an unequal distribution. In the national scenario, according to information from the Atlas of Waters and Wastewaters (ANA, 2015), $38.7 \%$ of the municipalities are supplied exclusively by groundwater, in the State of Rio Grande do Sul, this percentage is $57.6 \%$.

There is a major difference in urban and rural coverage of potable water services, as well as the sanitation management as a whole (WHO; UNICEF, 2017), it is noteworthy that Brazil has a large deficit of basic sanitation in its territory, especially in the distribution and quality of the water that reaches customer's tap (Castro et al., 2021).

As an aggravating circumstance, inadequate sanitation causes millions of fecal-oral route infections, mainly diarrhea, worldwide (Speich et al., 2016), which can lead to deleterious effects on human health (Wijesiri; Hettiarachchi, 2021). The authors estimate that 1.7 million people die every year due to contaminated water, 
lack of sanitation, and poor hygiene practices, in which $90 \%$ of them are children under 5 years old and live, mostly, in rural areas of developing countries.

The lack of financial resources for treatment operation and maintenance of treatment systems, inadequate technologies, lack of qualified professionals to manage and to supervise it are factors that practically preclude centralized supply and treatment systems in poor countries, because they are not accessible to a large part of the population, especially in regions with many rural and isolated communities (Baig et al., 2011).

The United Nations recognized the access to drinking water and sanitation as a basic human right, and that the ideal solution to waterborne related diseases is that their access is universal, affordable, safe and sufficient (Brow et al., 2016). Groundwater is one of the solutions, which according to the Brazilian Groundwater Association (ABAS, 2020), can be abstracted from different types of wells, which classification depends on its construction method, diameter, and depth.

Shallow wells present depths no higher than $20 \mathrm{~m}$ and diameters of about 1 $\mathrm{m}$. In Brazil, this type of well do not require government permission to be installed. The deep or artesian wells have higher vertical depths, being up to 2,000 $\mathrm{m}$ deep, and its diameter is from 4 into 36 in (ABAS, 2020).

Regarding water quality, groundwater physical, chemical, and microbiological characteristics are directly liked to its geology, rainfall, runoff, infiltration, and vegetation cover (Lerner; Harris, 2009). Moreover, groundwater quality is a result of anthropogenic activities developed in the hydrographic basin, through land use and land cover, management practices, disposal of wastewater in the watercourses and the soil, which are used as work units of water resources management (Marmontel et al., 2018).

In this context, the objective of this study was to evaluate the physical, chemical and microbiological characteristics of individual drinking water supply 
systems in the Northwest and Plateau region of Rio Grande do Sul state, Brazil, and relate it to an environmental macroscopic analysis.

\section{MATERIAL AND METHODS}

\subsection{Study area}

This study was developed in ten municipalities of Rio Grande do Sul state (Brazil), with drinking water samples collected between the years 2017 to 2019. Ametista do Sul (12 sampling points), Frederico Westphalen (4 sampling points), Palmeira das Missões (3 sampling points), Palmitinho (3 sampling points), Pinheirinho do Vale (3 sampling points), Planalto (3 sampling points), Seberi (3 sampling points), Taquaruçu do Sul (3 sampling points), Três de Maio (4 sampling points) and Vista Alegre (12 sampling points) (Figure 1).

Figure 1 - Location of the municipalities covered in the study

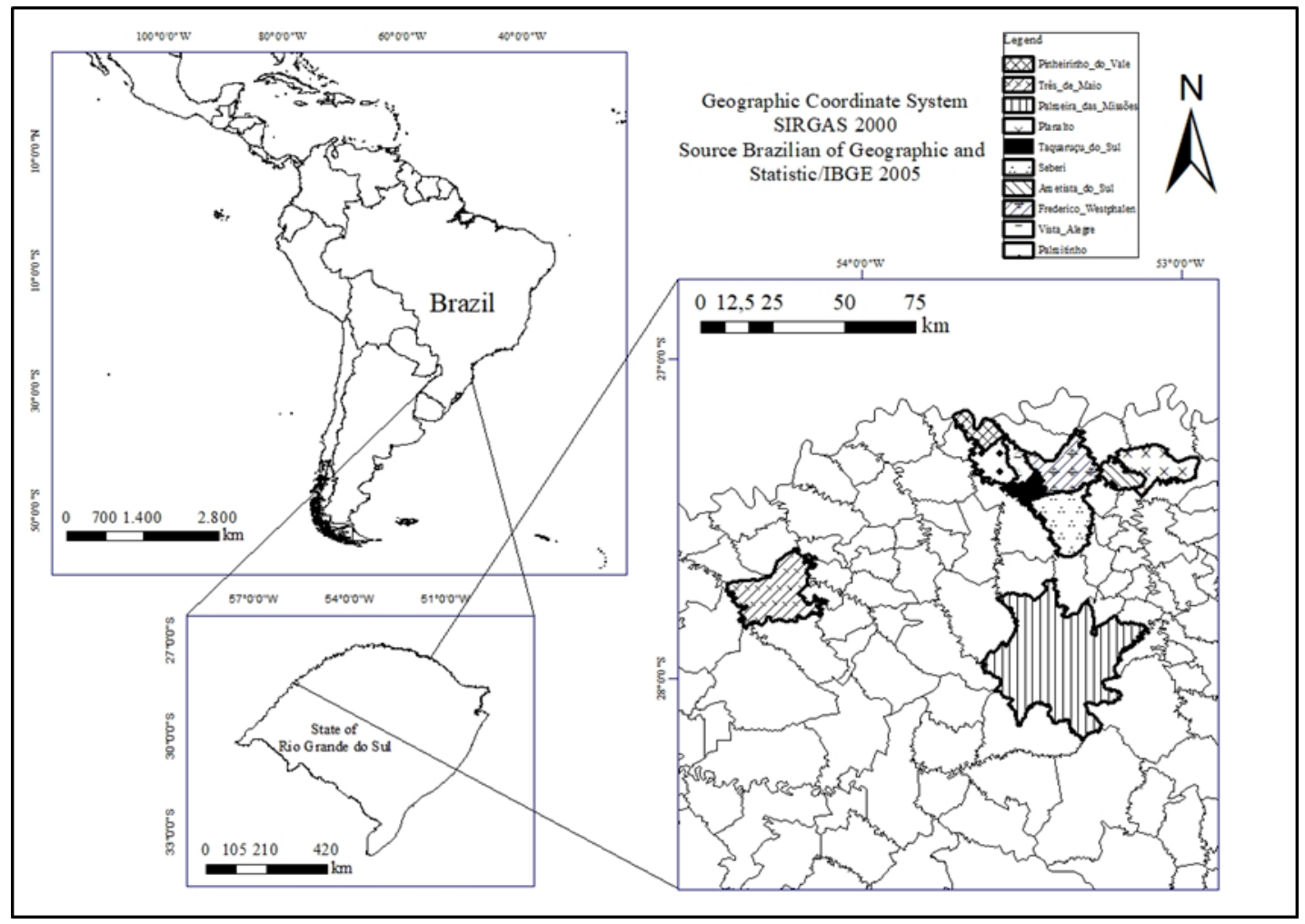

Fonte: Autores (2020) 
There were fifty sampling points. All water sampled was used for human consumption, $12 \%(6 / 50)$ of sampling points were located in the urban area and $88 \%(44 / 50)$ were located in the rural area of the municipalities, which the supply of these waters was provided by different sources: springs, shallow wells, and deep wells.

The region studied has a predominance of the Serra Geral I System, formed by fractured basaltic rocks, originated from acidic and basic lavas. For these reasons, the aquifer has a medium to high classification regarding the contamination vulnerability (CPRM, 2005).

\subsection{Sample collection and processing}

The water samples were collected in $500 \mathrm{~mL}$ Polyethylene bottles for physical and chemical analysis, except for water samples for biochemical oxygen demand $(\mathrm{DBO} 5,20)$ determination, which was stored in amber glass flasks. For microbiologic analysis, the samples were collected in $250 \mathrm{~mL}$ glass flasks appropriately autoclaved.

After collecting the samples, the flasks were stored in thermal boxes aiming to preserve the physical, chemical, and microbiological characteristics of water. Afterward, the samples were transported to the Water Resources Laboratory of the Federal University of Santa Maria at Frederico Westphalen to be analyzed. The variables $\mathrm{pH}$ and temperature were performed in loco through a portable $\mathrm{pHmeter.}$

The methods for physical, chemical, and microbiological analyzes were performed according to the Standard Methods for the Examination of Water and Wastewater (APHA et al. 2012) (Table 1). 
Table 1 - Methods used to analyze water quality variables

\begin{tabular}{|c|c|}
\hline Variables (units) & Method \\
\hline $\mathrm{pH}$ at $25^{\circ}$ & pHmeter / $4500-\mathrm{H}+\mathrm{B}$ \\
\hline True color (HU) & Spectrophotometric / 2120 B \\
\hline Apparent color (HU) & Spectrophotometric / 2120 B \\
\hline Turbidity (NTU) & Nephelometric / 2130 B \\
\hline Electrical conductivity $\left(\mu \mathrm{S} \mathrm{cm}^{-1}\right.$ ) & Conductivimeter / $2510 \mathrm{~B}$ \\
\hline Total alkalinity $\left(\mathrm{CaCO}_{3}\right)\left(\mathrm{mg} \mathrm{L}^{-1}\right)$ & Titrimetric / 2320 B \\
\hline Total hardness $\left(\mathrm{CaCO}_{3}\right)\left(\mathrm{mg} \mathrm{L}^{-1}\right)$ & Titrimetric / $2340 \mathrm{~B}$ \\
\hline Nitrite $\left(\mathrm{N}-\mathrm{NO}_{2}{ }^{-}\right)\left(\mathrm{mg} \mathrm{L}^{-1}\right)$ & Spectrophotometric / 4500- $\mathrm{NO}_{2}{ }^{-} \mathrm{B}$ \\
\hline Total phosphorus (P) (mg L-1) & Spectrophotometric / 4500-P C \\
\hline Fluoride $\left(\mathrm{F}^{-}\right)\left(\mathrm{mg} \mathrm{L}^{-1}\right)$ & Spectrophotometric / 4500-F- D \\
\hline Total iron $(\mathrm{Fe})\left(\mathrm{mg} \mathrm{L}^{-1}\right)$ & Spectrophotometric / 3120-B \\
\hline Biochemical Oxygen Demand $\left(\mathrm{BOD}_{5,20}\right)\left(\mathrm{mg} \mathrm{L}^{-1}\right)$ & Titrimetric / 5210-B \\
\hline Total coliforms (MPN $100 \mathrm{~mL}^{-1}$ ) & Multiple Tubes / $9221 \mathrm{~F}$ \\
\hline Escherichia coli (MPN/100 $\left.\mathrm{mL}^{-1}\right)$ & Multiple Tubes / $9221 \mathrm{~F}$ \\
\hline
\end{tabular}

Source: APHA et al. (2012)

\subsection{Environmental macroscopic analysis}

In addition to the physical, chemical, and microbiological variables, a macroscopic analysis was performed in $60 \%$ of the sampling points (30/50) according to a methodology proposed by Felippe and Magalhães Júnior (2012). The quantification considered in the macroscopic analysis can be observed in Table 2 .

Table 2 - Quantification of the macroscopic variable

\begin{tabular}{lccc}
\hline \multirow{2}{*}{ Macroscopic variables } & \multicolumn{3}{c}{ Quantification } \\
\cline { 2 - 4 } & Bad (1) & Medium (2) & Good (3) \\
Water color & Dark & Clear & Transparent \\
Water smells & Strong & Weak & Absent \\
Garbage around the supply systems & A lot & Little & Absent \\
Floating materials & & & \\
(solid waste in water) & A lot & Little & Absent \\
Foams & A lot & Little & Absent \\
Oils & A lot & Little & Absent \\
\hline
\end{tabular}


Schneider, S.I.; Golombieski, J.I.; Seben, D.; Menegazzo, K.C.; Wastowski, A.D.; Borba, W.F.; Decezaro,

\begin{tabular}{lccc}
\hline Conclusion & \multicolumn{3}{c}{ Quantification } \\
\cline { 2 - 4 } Macroscopic variables & Bad (1) & Medium (2) & Good (3) \\
\cline { 2 - 4 } Wastewater next to the supply system & Visible & Likely & Absent \\
Vegetation & Degraded or & Changed & Good condition \\
Water uses & absent & & There are not \\
Access & Constant & Sporadic & No access \\
\hline
\end{tabular}

Source: Felippe and Magalhães Júnior (2012)

Regarding the level of protection, Felippe and Magalhães Júnior (2012) suggest that water can be classified as Class A - Very Good, Class B - Good, Class C - Fair, Class D - Bad, and Class E - Very Bad, according to the range of scores (Table 3) obtained by the analysis of the variables (Table 2 ).

Table 3 - Water classification according to the level of protection of the sampling points surroundings

\begin{tabular}{|c|c|c|}
\hline Class & Level of protection & Final score* \\
\hline$A$ & Very Good & Between 31 to 33 points \\
\hline B & Good & Between 28 to 30 points \\
\hline C & Fair & Between 25 to 27 points \\
\hline D & Bad & Between 22 to 24 points \\
\hline $\mathrm{E}$ & Very Bad & Below 21 points \\
\hline
\end{tabular}

Source: Felippe and Magalhães Júnior (2012)

In were: * Score obtained by adding the quantified points in the macroscopic analysis

\subsection{Statistical analysis}

The statistical analysis was performed in the software Statistica ${ }^{\circledR} 7.0$ (StatSoft, 2004) and PAST ${ }^{\circledR}$ (Hammer et al., 2001). The Shapiro-Wilk test was applied to check the normality of data. When parametric, the Tukey test was used for multiple comparisons. However, for some data, even after transformation (log ( $\mathrm{x}$ $+1) ; \sqrt{x})$, normality was not achieved; in this case, the Kruskal-Wallis non- 
parametric test was used for independent multiple comparison samples. For all tests, significant differences were adopted for $p$-values ( $p \leq 0.05)$. Also, multivariate analysis was performed by principal components (PCA).

\section{RESULTS AND DISCUSSION}

\subsection{Water Quality}

In Table 4 are presented the physical, chemical and, microbiological variables of individual drinking water supply systems evaluated in springs, shallow wells, and deep wells.

Table 4 - Results of the physical, chemical and, microbiological variables of the individual supply systems analyzed

\begin{tabular}{|c|c|c|c|c|c|c|c|c|}
\hline \multirow{2}{*}{ Variables } & \multirow{2}{*}{\multicolumn{2}{|c|}{ MPV }} & \multicolumn{2}{|r|}{ Springs } & \multicolumn{2}{|c|}{ Shallow wells } & \multicolumn{2}{|r|}{ Deep wells } \\
\hline & & & $\mathbf{n}$ & \% (Min.-Max.) & $\mathbf{n}$ & \% (Min.-Max.) & $\mathbf{n}$ & \% (Min.-Max.) \\
\hline $\mathrm{pH}$ & $\begin{array}{l}6.0-9.5 \\
\text { (Brazil) }\end{array}$ & $\begin{array}{l}6.0-8.5 \\
(\mathrm{WHO})\end{array}$ & 8 & $87.5(5.8-8.1)$ & 15 & $80.0(4.0-8.2)$ & 27 & $74.1(5.5-10.2)$ \\
\hline Turbidity $^{1}$ & \multicolumn{2}{|c|}{5} & 8 & $75.0(0.5-63.1)$ & 15 & $53.3(0.1-36.3$ & 27 & $92.6(0.1-18.0)$ \\
\hline Nitrite $^{2}$ & 1 (Brazil) & $3(\mathrm{WHO})$ & 3 & $100.0\left(<\right.$ LOD $\left.^{8}-0.8\right)$ & 10 & $\begin{array}{c}100.0(<\text { LOD }- \\
0.9)\end{array}$ & 13 & 100.0 (<LOD) \\
\hline $\begin{array}{l}\text { Total } \\
\text { hardness } 3\end{array}$ & 300 (Brazil) & $500(\mathrm{WHO})$ & 3 & $100.0(27.3-59.7)$ & 13 & $\begin{array}{c}100.0(13.0- \\
75.8)\end{array}$ & 27 & $\begin{array}{c}100.0(0.9- \\
150.0)\end{array}$ \\
\hline $\begin{array}{l}\text { Apparent } \\
\text { color }^{4}\end{array}$ & \multicolumn{2}{|c|}{15} & 2 & $50.0\left(<\right.$ LOD $^{9}-75.3$ & 5 & $\begin{array}{c}40.0(<\text { LOD }- \\
458.74)\end{array}$ & 13 & $\begin{array}{c}92.3(<\text { LOD- } \\
68.8)\end{array}$ \\
\hline Total iron ${ }^{5}$ & \multicolumn{2}{|c|}{0.3} & 0 & - & 7 & $\begin{array}{c}28.6\left(<\mathrm{LOD}^{10}-\right. \\
2.1\end{array}$ & 5 & $\begin{array}{c}20.0(<L O D- \\
1.1)\end{array}$ \\
\hline Fluoride $^{6}$ & \multicolumn{2}{|c|}{1.5} & 3 & $100.0\left(<\right.$ LOD $\left.^{11}-0.7\right)$ & 9 & $\begin{array}{c}100.0(<\text { LOD }- \\
1.2)\end{array}$ & 11 & $\begin{array}{c}100.0(<\text { LOD }- \\
1.4)\end{array}$ \\
\hline $\begin{array}{l}\text { Total } \\
\text { coliforms }\end{array}$ & \multicolumn{2}{|c|}{ Absence in $100 \mathrm{~mL}$} & 8 & $0.0(29-8,275)$ & 15 & $0.0(2-27,750)$ & 27 & $0.0(1-3,980$ \\
\hline $\begin{array}{l}\text { Escherichia } \\
\text { coli }^{7}\end{array}$ & \multicolumn{2}{|c|}{ Absence in $100 \mathrm{~mL}$} & 8 & $0.0(11-1,360)$ & 15 & $6.7(0-5.300)$ & 27 & $7.4(0-80)$ \\
\hline
\end{tabular}

In were: MPV = Maximum permissible value according Brazilian Guideline (Brazil, 2021) and World Health Organization $(\mathrm{WHO}, 2017) \mathrm{n}=$ total number of points analyzed; $\%=$ Percentage of analyzed points that fall within the MPV according to Brazilian guidelines. (Min - Max) = Minimum and maximum values found by the study; $1 \mathrm{NTU} ; 2 \mathrm{mg} \mathrm{L}^{-1}$ of $\mathrm{N}^{-\mathrm{NO}^{2}} ; 3 \mathrm{mg} \mathrm{L}^{-1}$ of $\mathrm{CaCO}_{3} ; 4 \mathrm{HU} ; 5 \mathrm{mg} \mathrm{L}^{-1}$ of Fe; $6 \mathrm{mg} \mathrm{L}^{-1}$ of F; 7MPN $100 \mathrm{~mL}^{-1} ; 8<\mathrm{LOD}$ (Limit of Detection): nitrite (Range: 0.01 to $\left.0.1 \mathrm{mg} \mathrm{L}^{-1}\right) ; 9<\mathrm{LOD}$ : apparent color (12 to $1500 \mathrm{HU}) ; 10<$ LOD: total iron $\left(<0.02 \mathrm{mg} \mathrm{L}^{-1}\right) ; 11<\mathrm{LOD}$ : fluoride $\left(<0.02 \mathrm{mg} \mathrm{L}^{-1}\right)$ 
For $\mathrm{pH}$, it is observed that the major part of analyzed springs, shallow wells, and deep wells are in according to the Maximum Permissible Level given by Brazilian guidelines (Ordinance GM/MS nr. 888, May 04th 2021 (Brazil, 2021)) which is between 6.0 and 9.5 and with the World Health Organization (WHO, 2017) which is between 6.0 and 8.5. For deep wells, there were samples with $\mathrm{pH}$ above 10, which is related to geologic characteristics of the aquifer (ABAS, 2020). Oliveira and Galvão (2019), in deep well waters, corroborate with the here presented study and indicated that $\mathrm{pH}$ values are in the neutral band and according to the current Brazilian and WHO guidelines (Ramos et al., 2018; Portal et al., 2019).

In the major part of the analyzed points, the turbidity values were according to the maximum permissible values of Brazilian and WHO guidelines, as other studies exposed it (Oliveira et al., 2017). In this study, deep wells presented better turbidity results, because of the difficulty contamination sources have to reach waters of confined aquifers. Portal et al. (2019) found turbidity results similar to the present study, to shallow wells.

For the nitrite variable, all the sampling points, independently of the water origin, were considered appropriate for human consumption, for the reason that they presented values lower than the MPV of Brazilian Guidelines (Brazil, 2021), which is of $1 \mathrm{mg} \mathrm{L}^{-1}$ of $\mathrm{N}^{-N_{2}}$ - and WHO guidelines (WHO, 2017), which is of $3 \mathrm{mg} \mathrm{L-}$ 1 of $\mathrm{N}-\mathrm{NO}_{2}$. Similar results were also found in literature (Carasek et al., 2020; Dragon, 2021; Grumicker et al., 2018; Oliveira; Galvão, 2019; Portal et al., 2019;).

The total hardness, in all sampling points, is according to the current Brazilian (Brazil, 2021) and WHO guidelines (WHO, 2017); the values were lower than 300 and $500 \mathrm{mg} \mathrm{L}^{-1}$ of $\mathrm{CaCO}_{3}$. The geologic nature of the basin can be one interfering factor, being elevated in limestone regions and less significant in sand or clay terrains (Da Silva et al., 2018; Rossi et al., 2015). Other studies in the same region also present values similar to the here presented study, e.g., spring waters (Koch et al., 2017), drinking water supply to municipal schools (Da Silva et al., 2018). 
To the apparent color, it is evident that the hardest is the access to the water the lower interference in color, with almost all the results of deep wells presenting values lower than the MPV of $15 \mathrm{HU}$ according to Brazilian and WHO guidelines (Brazil, 2021; WHO, 2017). This result corroborates with other findings (Grumicker et al., 2018; Macedo et al., 2018). Consequently, natural and anthropogenic factors, especially those related to the use and occupation of soil, modify water properties and can make waters unacceptable for human consumption. These observations might be related to the values found in springs and shallow wells, which are similar to the results described by Koch et al. (2017).

Total iron in spring water was not analyzed. However, regarding shallow and deep wells, less than $30 \%$ were classified as acceptable to human consumption, according Brazilian and WHO guidelines (Brazil, 2021; WHO, 2017). The result is similar to other studies (Dragon 2021; Grumicker et al., 2018; Oliveira; Galvão, 2019).

To fluoride ion, all sampling points, in the present study, independently of water origin, are framed as appropriate to human consumption (Brazil, 2021; WHO, 2017), collaborating with Dragon (2021) and Oliveira and Galvão (2019) and analogous to the work of Grumicker et al. (2018).

Concerning the total coliforms, no water sample - independently of the type of individual water supply system - was adequate to human consumption, since the guidelines impose the absence of total coliforms and Escherichia coli in $100 \mathrm{~mL}^{-}$ 1 (Brazil, 2021; WHO, 2017). Figure 2 presents the concentrations of fecal contamination indicators found in the individual drinking water supply systems. Similar results were found by different authors (Portal et al., 2019; Oliveira; Galvão, 2019).

Galvan et al. (2020) highlight that total coliforms are microorganisms that are naturally present in the soil; therefore, they can be detected in groundwater. 
Moreover, the rainfall regime is a factor to be considered and there is a strong relationship between runoff and groundwater flow (Macedo et al., 2018).

Concerning microorganisms with exclusive fecal origin (E. coli), no spring is suitable for human consumption. However, some shallow and deep wells presented values within the limits established by the guidelines (Brazil, 2021; WHO, 2017). The samples of deep wells presented lower concentrations of total coliforms and E. coli statically different in comparison with the other two individual drinking water supply systems, according to figure 2.

The depth of the well is presumably a factor preventing contamination (Grumicker et al., 2018), to which is seemingly related to mainly domestic sewage and management of animal manure in rural properties (Galvan et al., 2020).

The effect of different use and occupation of soil and the conservation of riparian vegetation on water quality of headwater springs were also reported (Marmontel et al., 2018). Thus, the successful management and conservation of the various individual supply systems must take into account the quality and quantity of water (Rossi et al., 2015).

In this context, a way to improve water quality in rural communities could focus on water treatment at the domestic level and improvements in local sanitation (Brown et al., 2016; Martínez-Santos et al., 2017).

Brazilian law (Brazil, 2021) and the World Health Organization (WHO, 2017) do not establish MPVs for some variables namely: temperature, electrical conductivity, total alkalinity, true color, phosphorus, and BOD. In this sense, Table 5 shows an oscillation between the values found for these variables, according to the origin of the water. 
Table 5 - Values of the variables of the individual supply systems analyzed that do not have VMP by the Brazilian (Brazil, 2021) and World Health Organization Guidelines (WHO 2017)

\begin{tabular}{|c|c|c|c|c|c|c|}
\hline \multirow{2}{*}{ Variables } & \multicolumn{2}{|c|}{ Springs } & \multicolumn{2}{|c|}{ Shallow wells } & \multicolumn{2}{|c|}{ Deep wells } \\
\hline & $\mathbf{n}$ & Min - Max & $n$ & Min - Max & $\mathbf{n}$ & Min - Max \\
\hline Temperature $^{1}$ & 3 & $20.0-25.0$ & 10 & $14.7-31.0$ & 13 & $14.0-31.0$ \\
\hline $\begin{array}{l}\text { Eletrical } \\
\text { conductivity }{ }^{2}\end{array}$ & 3 & $74.0-136.2$ & 13 & $69.0-197.0$ & 22 & $48.5-470.6$ \\
\hline $\begin{array}{l}\text { Total } \\
\text { alkalinity }\end{array}$ & 3 & $17.1-62.1$ & 11 & $8.0-142.0$ & 21 & $12.2-268.0$ \\
\hline True Color ${ }^{4}$ & 2 & $<$ LOD-37.9 & 5 & $<$ LOD -100.8 & 8 & $<$ LOD -27.7 \\
\hline $\begin{array}{l}\text { Total } \\
\text { phosphorus }\end{array}$ & 5 & $0.01-0.05$ & 3 & $0.01-0.60$ & 2 & 0.10 \\
\hline $\mathrm{BOD}_{5,20^{6}}$ & 5 & $0.06-2.7$ & 2 & $0.1-3.9$ & 0 & - \\
\hline
\end{tabular}

In were: $n=$ total number of points analyzed. Min - Max = minimum and maximum results found in each variable. ${ }^{10} \mathrm{C}_{;}{ }^{2} \mathrm{\mu S} \mathrm{cm}-1 ;{ }^{3} \mathrm{mg} \mathrm{L}^{-1}$ of $\mathrm{CaCO}_{3} ;{ }^{4} \mathrm{HU} ;<\mathrm{LOD}$ (Limit of Detection): True color $(12-1500 \mathrm{HU}) ; \mathrm{mg} \mathrm{L}^{-1}$ of $\mathrm{P} ;{ }^{6} \mathrm{mg} \mathrm{L}^{-1}$ of $\mathrm{BOD}_{5,20}$;

Regarding temperature, the values found in the present study were close to those of the springs assessed by Ramos et al., (2018) and deep wells (Macedo et al., 2018; Oliveira; Galvão, 2019; Shehab et al., 2021).

The electrical conductivity values are similar to those found by Ramos et al. (2018) and Dragon (2021). Eletrical condutivity values may have a connection with soil characteristics and geological structure. In deep wells, waters with low ion concentrations may indicate the water residence time in the aquifer, contributing to a context of an aquifer being recharged locally by rainwater and/or nearby rivers (Oliveira; Galvão, 2019). However, in shallow wells, values higher than the present study may indicate impacted environment or waters with corrosive properties, being also influenced by mineral composition, recharge rates or even saline intrusion (Portal et al., 2019).

Regarding the total alkalinity, the concentrations presented great variation, especially in the deep wells. Nwankwoala and Peterside (2019) evaluating calcium 
ions $\left(\mathrm{Ca}^{2+}\right)$ in water from shallow wells, found values similar to those of the springs of the present work and showing for total alkalinity and other analyzed variables, a considerable variation with the local geology, geomorphology, and degree of use of waters.

The true color variable also does not have a MPV according to current Brazilian and WHO guidelines, however, it is possible to assume that the less the access to the water, the lower are the physical changes caused by natural and anthropogenic interventions. Oscillation in the true color values of shallow wells similar to the present study, was justified by the presence of pasture and natural vegetation close to the sampling site (Saling et al., 2017), which might also be caused by humic compounds, algae, minerals, protozoa and the presence of colloids, e.g., $\mathrm{Fe}$ and $\mathrm{Mn}$, which need to be removed for water through precipitation. The variability of the obtained values for this variable is mainly attributed to the spatial distribution in which the wells are found, being influenced by the local geology (Amorim et al., 2010).

For the BOD variable the values, for springs and shallow wells, were similar to Shehab et al. (2021), Nwankwoala and Peterside (2019) and Gupta et al., (2017). In regards to total phosphorus, the rainy periods and eutrophication of springs with close agriculture use are possible interferents (Lerner; Harris, 2009; Marmontel et al., 2018). Moreover, the presence of phosphorus and BOD can be related to sewage discharged close to water resources. Nwankwoala and Peterside (2019) checked values similar to the present study, in shallow wells waters, with higher values obtained in those in absence of conservation in their surroundings.

Figure 3 provides a better interpretation of the four variables analyzed at all collection points ( $\mathrm{pH}$, turbidity, total coliforms, and E. coli) with the final result of the principal components analysis (PCA). 
Figure 3 - Principal Components Analysis (PCA), where the blue dots are springs, the red dots are shallow wells, and the black dots are deep wells

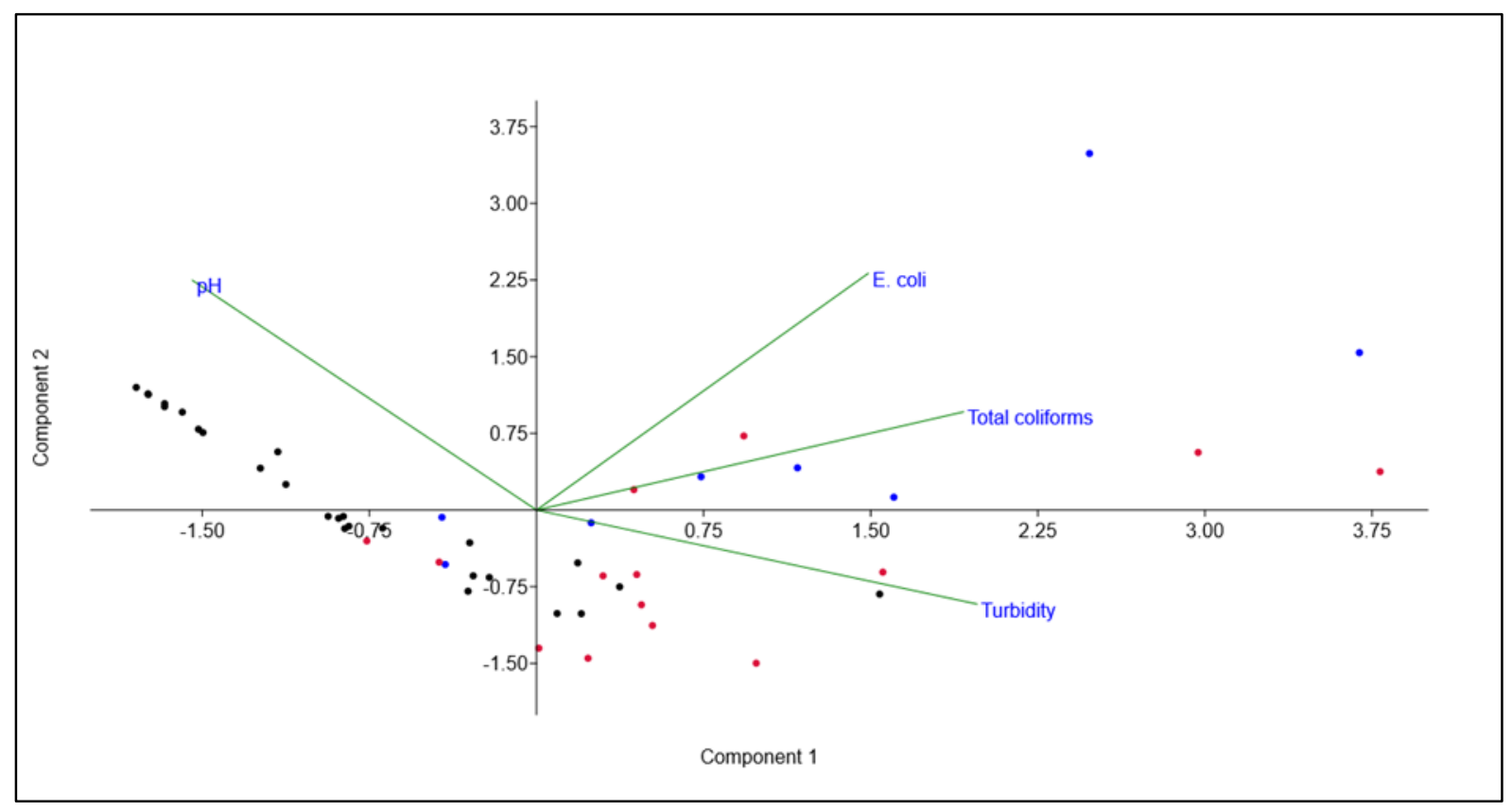

Source: Authors (2020)

The first two axes of the PCA explained $67.70 \%$ of the total variation of the analyzed data. The first canonical axis explained $46.41 \%$ of the variation and distinguished the variables E. coli, total coliforms, and turbidity (positive loading) from the $\mathrm{pH}$ variable. The water quality variables with the greatest contribution in the first axis were total coliforms and turbidity. Although not so clear, could be noticed a tendency to separate the collection points of deep wells in relation to springs and shallow wells, possibly, due to the greater vulnerability to the contamination of the more superficial waters. The $\mathrm{pH}$ was associated with water samples from deep wells. The second canonical axis explained $21.29 \%$ of the data variation, and the water quality variables with the greatest contribution were $\mathrm{pH}$, and E. coli. Similarly, could be observed the relationship between the $\mathrm{pH}$ of the water and the deep wells, probably related to the composition of the local rocks and soil. 


\subsection{Environmental Macroscopic Analysis}

Figure 4 shows the results, in percentage, of the classification according to the macroscopic analysis performed in each point, as well as average score, as an effect of comparison, of the different individual water supply systems.

Figure 4 - Macroscopic analysis classification (I) and the average score obtained by individual supply systems (II)

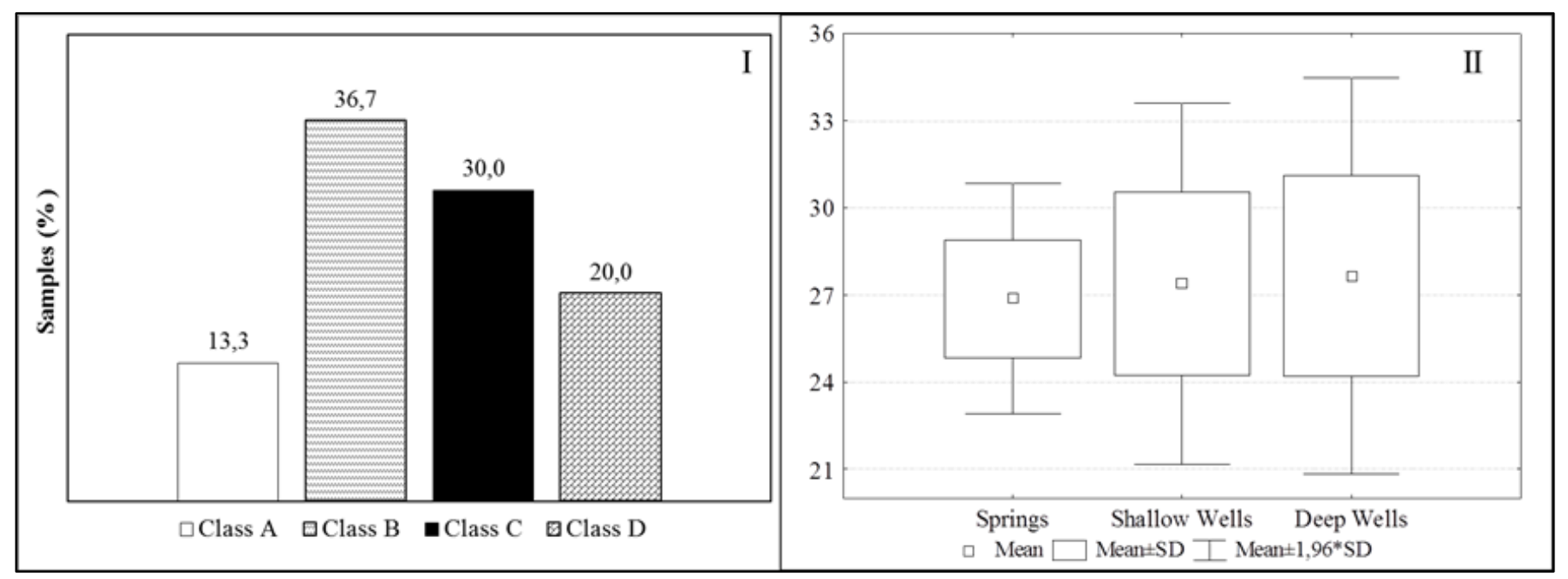

Source: Authors (2020)

The largest number of sampling points was framed in class B. It should be noted the absence of a class E. However, only $13 \%(4 / 30)$ of the sampling points were considered class A - very good - due to the good conservation of the location, making it difficult the access to water by people and animals, presenting a good area of vegetation surrounding the spring, absence of solid waste, sewage, oils, foams, and smells in the water. In class B, considered good, there are approximately $37 \%(11 / 30)$ of the analyzed points. Also, half of the points were considered in class $C$ and $D$, fair and bad, respectively.

The results obtained in this study corroborate to others (Galvan et al., 2020), with a lower percentage of conserved springs, while the majority are highly degraded due to the lack of protection and the proximity to housings (Martínez- 
Santos et al., 2017). Santos and dos Santos (2021) verified the classification C (fair) and $D($ bad) in their sampling points.

When compared to different supply systems, the anthropogenic interferences from environmental macroscopic analysis were similar, independently of the depth of individual supply systems $(p>0.05)$. The springs obtained an average score of $26.9 \pm 2.0$, the shallow wells of $27.4 \pm 3.2$, and the deep wells of $27.7 \pm 3.5$.

The groundwater quality is related to the outside, land use and land cover, due to point and nonpoint sources of contamination (Lerner; Harris, 2009; Marmontel et al., 2018; Carasek et al., 2020). It is important to highlight that shallow and deep wells are drilled, many of them without authorization and the proper protections, creating a direct environmental contamination pathway from the surface to groundwater, affecting its potability (Lerner; Harris, 2009; MartínezSantos et al., 2017).

In this scenario, in the matter of public health, there is evidence of a serious threat situation, by the presence of springs and wells that, vulnerable to contamination, offer poor quality water to consumption, as it is demonstrated to the elevated contamination of total coliforms and E. coli. Besides there is the need of periodic monitoring and treatment of these waters, at least, disinfection, thus adopting better practices that provide protection and contamination risk reduction of well waters (Oliveira et al., 2017; Schuitema et al., 2020).

\section{CONCLUSION}

This paper evidenced that groundwater in the Northwest and Plateau region of Rio Grande do Sul state, Brazil, is vulnerable to contamination. However, some aspects, e.g., individual supply system depth, are able to facilitate the access to water, but also cause the interferences, natural or anthropogenic, that influence physical, chemical and, microbiological characteristics of water quality. 
Besides, the environmental conditions, e.g., conservation of water source location, through vegetation, the difficulty of access, absence of solid waste and wastewater in the surroundings of these systems protect water quality.

Concerning water quality, due to higher values than the current Brazilian and WHO guidelines, the individual supply systems presented fecal contamination, with the presence of Escherichia coli; therefore, posing as a risk to human health.

A trend towards greater contamination in shallower waters is related to the ease of possible entry of rainwater, transport of solid and liquid waste, and lack of protection in its surroundings.

Independently of origin of water, spring, shallow well or deep well, it is necessary the disinfection treatment for pathogens elimination and later the destination to human consumption.

\section{ACKNOWLEDGEMENTS}

The authors would like to thank all undergraduate students who are part of the GMA (Grupo de Pesquisa em Monitoramento Ambiental of CNPq) and, that participated in this study.

\section{REFERÊNCIAS}

ABAS - Associação Brasileira de Águas Subterrâneas. Poços de captação de água (Groundwater wells) Brazilian Association of Groundwater. 2020. https://www.abas.org/pocos-paracaptacao-de-agua/ (accessed 23 October 2020)

Amorim, J. R. A.; Cruz, M. A. S.; Resende, R. S. Groundwater quality for irrigation purposes in Piauí River Basin in the State of Sergipe, Brazil. Revista Brasileira de Engenharia Agrícola e Ambiental, 14: 804-811, 2010.

ANA - Agência Nacional de Águas. Atlas Água e Esgoto (Water and Sewage Atlas), National Agency of Water. Brasília. 2015.

APHA; AWWA; WEF. Standard Methods for the Examination of water and wastewater. 22 nd edition. American Public Health Association, American Water Works Association, Water Environmental Federation. Washington, DC, USA. 2012. 
Baig, S. A.; Mahmood, Q.; Nawab, B.; Shafqat, M. N.; Pervez, A. Improvement of drinking water quality by using plant biomass through household biosand filter - A decentralized approach. Ecological Engineering, 37: 1842-1848, 2011.

Brazil. Ordinance GM/MS nr. 888, May 2021. Control and surveillance procedures for the quality of water for human consumption and its potability standard. Ministry of Health / Minister's Office, 2021.

Brown, C.; Neves-Silva, P.; Heller, L. The human right to water and sanitation: a new perspective for public policies. Ciência \& Saúde Coletiva, 21: 661-670, 2016.

Carasek, F. L.; Baldissera, R.; Oliveira, J. V.; Scheibe, L. F.; Magro, J. D. Quality of the groundwater of the Serra Geral Aquifer System of Santa Catarina west region, Brazil. Groundwater for Sustainable Development, 10: 100346, 2020.

Castro, M. A. B.; Guimarães, A. A.; De Oliveira, G. H. B.; Silva, R. S.; Franco. Proposta de dispositivo de baixo custo para monitoramento da qualidade da água. Communications and Innovations Gazette, 5: 44-55, 2021

CPRM - Serviço Geológico do Brasil. Projeto Mapa Hidrogeológico do Estado do Rio Grande do Sul (Rio Grande do Sul State Hydrogeological Map Project). Final Report. Porto Alegre. 2005.

Da Silva, A.; De Brito, J. M.; Duarte, J. S.; Braz, A. S.; Silva, R. de A.; Silva Filho, E. D. Physicalchemical analysis of the water used for consumption in the municipal schools of the urban area of Esperança/PB. Biota Amazônia, 8: 49-52, 2018.

Dragon, K. Identification of groundwater conditions in the recharge zone of regionally extended aquifer system with use of water chemistry and isotopes (Lwowek region, Poland), Journal of Hydrology: Regional Studies, 34: 100787, 2021.

Felippe, M. F.; Magalhães Júnior, A. P. Impactos ambientais macroscópicos e qualidade das águas em nascentes de parques municipais em Belo Horizonte-MG. Geografias, 8: 8-23, 2012.

Galvan, K. A.; Medeiros, R. C.; Martins Neto, R. P.; Liberalesso, T.; Golombieski, J. I.; Zanella, R. Macroscopic environmental analysis and water quality of springs in São Domingos Watershed/SC, Brazil. Revista Ibero Americana de Ciências Ambientais, 11: 165-176, 2020.

Grumicker, M. G.; Batista-Silva, V. F.; Bailly, D.; Silva, A. F. G. da; Ruaro, R., Moraes A. R. de. Qualidade da água de poços artesianos em um assentamento do município de Mundo Novo, Mato Grosso do Sul. Revista Gestão e Sustentabilidade Ambiental, 7: 807-821, 2018.

Gupta, N.; Pandey, P.; Hussain, J. Effect of physicochemical and biological parameters on the quality of river water of Narmada, Madhya Pradesh, India. Water Science, 31: 11-23, 2017.

Hammer, Ø., Harper, D. A. T.; Ryan, P. D. PAST: Paleontological Statistics software package for education and data analysis. Palaeontologia Electronica, 4(1): 1-9, 2001. 
Koch, F. F.; Kauffmann, C.; Bica, J. B.; Adami, F. S.; Stevens, J. F.; Eckhard, C. L.; Oliveira, E. C. de. Surface water analysis used for human consumption in a Rio Grande do Sul community. Revista Caderno Pedagógico, 14: 36-50, 2017.

Lerner, D. N.; Harris, B. The relationship between land use and groundwater resources and quality. Land Use Policy, 265: 5265-5273, 2009.

Macedo, T. de L.; Rempel, C.; Maciel, M. J. Análise físico-química e microbiológica de água de poços artesianos em um município do Vale do Taquari-RS. Tecno-lógica, 22: 58-65, 2018.

Marmontel, C. V. F.; Lucas-Borja, M. E.; Rodrigues, V. A.; Zema D. A. Effects of land use and sampling distance on water quality in tropical headwater springs (Pimenta creek, São Paulo State, Brazil). Science of The Total Environment, 622-623: 690-701, 2018.

Martínez-Santos, P.; Martín-Loeches, M.; García-Castro, N.; Solera, D.; Díaz-Alcaide, S.; Montero, E.; García-Rincón, J. A survey of domestic wells and pit latrines in rural settlements of Mali: Implication of on-site sanitation on the quality of water supplies. International Journal of Hygiene and Environmental Health, 220: 1179-1189, 2017.

Nwankwoala, H. O.; Peterside, A. N. Hydrochemical Characterization of Groundwater and Surface Water Sources in parts of Southern Ijaw Local Government Area, Bayelsa State, Nigeria. International Journal of Geology \& Earth Science, 5: 46-72, 2019.

Oliveira, J. S. C.; Medeiros, A. M.; Castor, L. G.; Carmo, R. F.; Bevilacqua, P. D. Individual water supply solutions: issues for environmental health surveillance. Caderno de Saúde Coletiva, 25: 217-224, 2017.

Oliveira, D. A.; Galvão P. Geometry and water quality of the unconfined aquifer near the Piracicaba river, Ipatinga/MG, Brazil. HydroResearch, 2: 31-39, 2019.

Portal, T. P.; Pedlowski, M. A.; De Almeida, C. M. S.; Canela, M. C. An integrated assessment of water quality in a land reform settlement in northern Rio de Janeiro state, Brazil. Heliyon, 5: 118, 2019.

Ramos, S. T. B.; Mafra, M. S. H.; Rech, T. D.; Siegloch, A. E.; Rech, A. F. Water quality of springs in areas under different land uses in the southern highlands of Santa Catarina. Revista Ambiente \& Água, 13: 1-10, 2018.

Rossi, P. M.; Marttila, H.; Jyvasjarvi, J.; Ala-aho, P.; Isokangas, E.; Muotka, T.; Klove B. Environmental conditions of boreal springs explained by capture zone characteristics. Journal of Hidrology, 531: 992-1002, 2015.

Saling, C.; Graff, A.; Oliveira, E. C.; Bockel, W. J. Avaliação da qualidade da água de poços rasos no município de Colinas-RS. Tecno-lógica, 21: 59-64, 2017.

Santos, D. R. C. da S; dos Santos, V. C. Impactos ambientais macroscópicos e qualidade da água em nascentes localizadas na Vila Bananeira, Arapiraca-AL. Diversitas Jounal, 6: 481- 498, 2021. 
Schuitema, G.; Hooks, T.; McDermott, F. Water quality perceptions and private well management: The role of perceived risks, worry and control. Journal of Environmental Management, 267: 110654, 2020.

Shehab, Z. N.; Jamil, N. R.; Aris, A. Z.; Shafie, N. S. Spatial variation impact of landscape patterns and land use on water quality across an urbanized watershed in Bentong, Malaysia. Ecological Indicators, 122: 107254, 2021.

Speich, B.; Croll, D.; Furst, T.; Utzinger, J.; Keiser, J. Effect of sanitation and water treatment on intestinal protozoa infection: a systematic review and meta-analysis. Lancet Infectious Diseases, 16: 87-99, 2016.

Wijesiri, B.; Ehettiarachchi, A. How gender disparities in urban and rural areas influence access to safe drinking water. Utilities Policy, 16: 101141, 2021.

WHO - World Health Organization. Guidelines for drinking water quality: Fourth Edition incorporating the first addendum. WHO Library Cataloguing-in-Publication Data, Geneva. 2017.

WHO; UNICEF - World Health Organization and United Nations Children's Fund. Progress on drinking water, sanitation and hygiene. Geneva. 2017.

\section{CONTRIBUIÇÃO DOS AUTORES}

\section{1 - Silvana Isabel Schneider}

Environmental and Sanitary Engineer, Federal University of Santa Maria, campus

Frederico Westphalen (UFSM-FW), Brazil

0000-0002-8524-5669 - silvanaeas@outlook.com

Contribuição: Conceptualization, Methodology, Visualization, Writing - original draft

\section{2 - Jaqueline Ineu Golombieski}

Biologist, Animal Biodiversity PhD, Professor at Department of Engineering and Environmental Technology at Federal University of Santa Maria (UFSM-FW), Brazil 0000-0001-7096-1972 - jaqueline.golombieski@ufsm.br

Contribuição: Conceptualization, Data curation, Formal Analysis, Funding acquisition, Investigation, Methodology, Project administration, Resources, Supervision, Validation, Visualization, Writing - original draft, Wriing - review \& editing

\section{3 - Debora Seben}

Environmental and Sanitary Engineer, Master in Environmental Science and Technology UFSM-FW

0000-0001-7990-3146 - debyseben@hotmail.com

Contribuição: Conceptualization, Methodology, Investigation, Visualization, Writing original draft 


\section{4 - Kananda Cabral Menegazzo}

Environmental and Sanitary Engineer, Federal University of Santa Maria(UFSM-FW), Brazil

0000-0001-8246-2222 - kanandacabralmenegazzo@gmail.com

Contribuição: Conceptualization, Methodology, Investigation

\section{5 - Arci Dirceu Wastowski}

Industrial Chemist, Chemistry PhD, Professor at Department of Engineering and Environmental Technology at Federal University of Santa Maria (UFSM-FW), Brazil 0000-0003-0255-5125 - wastowski@ufsm.br

Contribuição: Funding acquisition, Methodology, Resources

\section{6 - Willian Fernando de Borba}

Environmental and Sanitary Engineer, Civil Engineering PhD, Professor at Department of Engineering and Environmental Technology at Federal University of Santa Maria (UFSM-FW), Brazil 0000-0001-5717-1378 - borbafw@gmail.com

Contribuição: Conceptualization, Methodology, Investigation, Visualization, Writing original draft

\section{7 - Samara Terezinha Decezaro}

Environmental and Sanitary Engineer, Civil Engineering PhD, Professor at Department of Engineering and Environmental Technology at Federal University of Santa Maria (UFSM-FW), Brazil

0000-0002-0812-7749 - samaradecezaro@hotmail.com

Contribuição: Conceptualization, Methodology, Investigation, Visualization, Writing original draft

\section{8 - Raphael Corrêa Medeiros}

Environmental Engineer, Science PhD, Professor at Department of Engineering and Environmental Technology at Federal University of Santa Maria (UFSM-FW), Brazil 0000-0002-7090-1731 - medeiroscg@yahoo.com.br Contribuição: Conceptualization, Data curation, Formal Analysis, Funding acquisition, Investigation, Methodology, Resources, Supervision, Validation, Visualization, Writing original draft, Wriing - review \& editing 